\title{
Effect of Somatostatin-Induced Insulinopenia on Glucose Oxidation in Man
}

\author{
J.P.Felber ${ }^{1}$, D. Thiébaud ${ }^{1}$, E. Maeder ${ }^{1}$, E. Jéquier ${ }^{2}$, R. Hendler ${ }^{3}$ and R. A. DeFronzo ${ }^{3}$ \\ ${ }^{1}$ Division of Clinical Biochemistry, Lausanne University Hospital, ${ }^{2}$ Institute of Physiology, University of Lausanne, Lausanne, Switzerland, and \\ ${ }^{3}$ Department of Medicine, Yale University, School of Medicine, New Haven, Connecticut, USA
}

Summary. In the basal state the body utilizes glucose at a rate of $2.2-2.3 \mathrm{mg} \cdot \mathrm{kg}^{-1} \cdot \mathrm{min}^{-1}$; of this approximately 1.2 $1.3 \mathrm{mg} \cdot \mathrm{kg}^{-1} \cdot \mathrm{min}^{-1}$ is oxidized, while the remaining $1.0 \mathrm{mg}$. $\mathrm{kg}^{-1} \cdot \min ^{-1}$ must be utilized by non-oxidative pathways. Little information is, however, available concerning the insulin dependency of these processes. To examine the role of basal insulin levels on glucose oxidation, glucose storage and total body glucose uptake, somatostatin $(10 \mu \mathrm{g} / \mathrm{min})$ was infused for $2 \mathrm{~h}$ in nine volunteers while maintaining plasma glucose concentration constant at basal levels by an exogenous glucose infusion. Basal plasma insulin fell by about $50 \%$ (13 \pm 2 to $7 \pm 1 \mathrm{mU} / 1, p<0.01$ ). Total body glucose metabolism $\left({ }^{3} \mathrm{H}\right.$-3-glucose) declined from $2.3 \pm 0.1$ to $1.9 \pm 0.1 \mathrm{mg}$. $\mathrm{kg}^{-1} \cdot \min ^{-1}(p<0.01)$. This decrease was entirely accounted for by a fall in basal glucose oxidation (measured by indirect calorimetry) from $1.3 \pm 0.1$ to $0.7 \pm 0.1 \mathrm{mg} \cdot \mathrm{kg}^{-1} \cdot \mathrm{min}^{-1}(p<$ $0.001)$. To assess the specific role of insulin deficiency in the decline in glucose oxidation, subjects were restudied with somatostatin plus basal insulin replacement $\left(0.07 \mathrm{mg} \cdot \mathrm{kg}^{-1}\right.$. $\left.\mathrm{min}^{-1}\right)$. Fasting insulin concentration $(14 \pm 1 \mathrm{mU} / \mathrm{l})$ remained constant during somatostatin plus insulin infusion $(13 \pm$ $1 \mathrm{mU} / \mathrm{l})$ and basal rates of glucose oxidation $(1.2 \pm 0.1 \mathrm{mg}$. $\mathrm{kg}^{-1} \cdot \min ^{-1}$ ) and total body glucose uptake did not change significantly. After $2 \mathrm{~h}$, the basal insulin infusion was stopped and somatostatin was continued. Over the subsequent hour, glucose oxidation declined by $0.4 \pm 0.1 \mathrm{mg} \cdot \mathrm{kg}^{-1} \cdot \mathrm{min}^{-1}$. This decrease was associated with a parallel decrease in total body glucose uptake of $0.4 \pm 0.1 \mathrm{mg} \cdot \mathrm{kg}^{-1} \cdot \mathrm{min}^{-1}$. These results indicate that approximately $50 \%$ of basal glucose oxidation is dependent upon basal insulin secretion. Non-oxidative pathways of glucose metabolism under basal conditions appear to be insulin independent.

Key words: Somatostatin, indirect calorimetry, glucose oxidation, insulin deficiency.
The response of hepatic and peripheral tissues to exogenously infused or endogenously secreted insulin has been well characterized [1-4]. However, much less is known about the effect of basal insulin levels on glucose metabolism. In post-absorptive man, the body utilizes glucose at the rate of approximately $2.2 \mathrm{mg} \cdot \mathrm{kg}^{-1}$. $\min ^{-1}$ [5]. Of this, about $1.2-1.3 \mathrm{mg} \cdot \mathrm{kg}^{-1} \cdot \mathbf{m i n}^{-1}$ is oxidized [1]. The difference between basal glucose uptake and basal glucose oxidation is about $0.9-1.0 \mathrm{mg}$. $\mathrm{kg}^{-1} \cdot \mathrm{min}^{-1}$. This represents non-oxidative glucose disposal by all tissues other than brain and includes uptake by the splanchnic area, recycling via glycolysis, conversion to lipid, and gluconeogenesis. The qualitative and quantitative aspects of these various processes have been reviewed in detail previously [1]. What role insulin may play in the non-oxidative as well as oxidative disposal of glucose in the basal state is still unknown. In the present study, we have attempted to combine somatostatin infusion with indirect calorimetry [6] and the in- sulin clamp technique [7] to determine the effect of acute insulinopenia on the oxidative and non-oxidative pathways involving glucose utilization during the postabsorptive state in normal man.

\section{Subjects and Methods}

\section{Subjects}

Nine healthy male volunteers, age range $21-26$ years (mean \pm SEM $23 \pm 1$ years) participated in the study. Their ideal body weight (based on medium frame individuals from the Metropolitan Life Insurance Tables [8]) ranged from 90 to $101 \%$ (mean $96 \pm 2 \%$ ), and their absolute weight ranged from 63 to $79 \mathrm{~kg}$ (mean $68 \pm 4 \mathrm{~kg}$ ). No subject had a family history of diabetes mellitus and none was taking any medication. All were consuming a weight-maintaining diet containing at least $250-300 \mathrm{~g}$ of carbohydrate per day for 3 days before each study. Prior to their participation, the nature, purpose, and risks of the study were explained to all subjects who gave their voluntary consent. The experimental protocol was approved by the Human Investigation 
Committee of the Department of Medicine of the University of Lausanne, Switzerland.

\section{Experimental Protocol}

All studies were performed with subjects in the recumbent position and started at $08.00 \mathrm{~h}$ following a $10-12 \mathrm{~h}$ overnight fast. A Teflon catheter was inserted into an antecubital vein for the infusion of all test substances. For blood sampling a second catheter was inserted retrogradely into the wrist vein and kept patent with an infusion of isotonic saline. The hand was then inserted into a heated box (air at $70^{\circ} \mathrm{C}$ ) to achieve arterialization of the venous blood. The $3-\mathrm{H}^{3}$-glucose infusion and continuous respiratory exchange measurements were initiated 120 and $60 \mathrm{~min}$, respectively, before beginning the somatostatin infusion. Both the ${ }^{3} \mathrm{H}$-3-glucose infusion and respiratory exchange measurements were continued throughout the duration of all the experimental protocols.

\section{Somatostatin Infusion and Euglycaemic Clamp}

Somatostatin was infused at a constant rate of $10 \mu \mathrm{g} / \mathrm{min}$ for $2 \mathrm{~h}$ in nine subjects. No insulin replacement was given. During the third hour, the somatostatin infusion was stopped while the continuous respiratory measurements were continued. Throughout the study period, plasma glucose concentration was maintained constant at basal pre-infusion levels by determination of the plasma glucose concentration every $5 \mathrm{~min}$ and periodically adjusting a variable $20 \%$ glucose solution based on a negative feedback principle [7]. In four subjects, the above protocol was repeated, but an insulin replacement infusion $\left(0.07 \mathrm{mg} \cdot \mathrm{kg}^{-1} \cdot \min ^{-1}\right)$ was administered for the first $2 \mathrm{~h}$. After $2 \mathrm{~h}$, the insulin infusion was stopped and somatostatin was continued for an additional hour. In subjects who participated in repeated studies, the second study was performed 1-3 weeks after the first. In all studies, tritiated glucose was infused as described below to follow changes in hepatic glucose production and glucose disposal.

\section{Respiratory Exchange Measurements}

During the $60 \mathrm{~min}$ control period and throughout the 3 -h experimental protocol, substrate utilization rates were determined by computerized open-circuit indirect calorimetry using a ventilated hood as previously described [6]. Briefly, a transparent plastic hood was placed over the subject's head and made air tight around the neck. To avoid air loss, a slight negative pressure was maintained in the hood. Ventilation was measured with a massic flowmeter (Setaram, Lyon, France). A constant fraction of the air flowing out of the hood was automatically collected for analysis. The oxygen content was continuously measured by a thermomagnetic analyzer (Magnos, Hartmann \& Braun, Frankfurt, FRG) and carbon dioxide content by an infrared analyzer (Uras 2T, Hartmann \& Braun). The non-protein respiratory quotient was calculated from calorimetric values and urinary nitrogen [9]. Determination of the carbohydrate oxidation rate was obtained by using the table of Lusk [10] for non-protein respiratory quotient which is based on 0.707 RQ for $100 \%$ fat oxidation and 1.00 for $100 \%$ carbohydrate oxidation. The quantity of urinary nitrogen excreted during the study period was used to obtain an index of the amount of protein oxidized assuming that protein oxidation was relatively constant. It should be noted, however, that this assumption does not substantially affect the calculation of carbohydrate oxidation [11].

\section{Glucose Kinetics}

Two hours before each study, a priming infusion of $25 \mu \mathrm{Ci}$ of ${ }^{3} \mathrm{H}-3$ glucose (New England Nuclear, Boston, Massachussetts, USA) was administered. This was followed immediately by a continuous infusion at the rate of $0.25 \mu \mathrm{Ci} / \mathrm{min}$. Plasma samples for ${ }^{3} \mathrm{H}-3$-glucose specific activity were drawn at $30,60,75,90$ and at 5 min intervals thereafter. In all subjects, a steady-state plateau of tritiated glucose specific activity was achieved during the last $30 \mathrm{~min}$. After $2 \mathrm{~h}$ of ${ }^{3} \mathrm{H}$-3-glucose infusion, the somatostatin infusion was begun and plasma samples for tritiated glucose specific activity were drawn at $10-15 \mathrm{~min}$ intervals for the subsequent $3 \mathrm{~h}$.

\section{Analytical Procedures}

Plasma glucose concentration was determined in duplicate by the glucose oxidase method using a Beckman glucose analyzer II (Beckman Instruments, Fullerton, California, USA). Plasma immunoreactive insulin and glucagon were determined by radioimmunoassay as described by Herbert et al. [12] and Aguilar-Parada et al. [13]. Plasma non-esterified fatty acids (NEFA) were extracted using the method of Dole and Meinertz [15] and determined according to the method of Heindel et al. [15]. Ketone bodies ( $\beta$-hydroxybutyrate and acetoacetate) were determined by an enzymatic method according to Williamson and Mellamby [16]. Plasma catecholamines (adrenaline and noradrenaline) were determined by a radioenzymatic assay as described previously [17]. Urinary nitrogen was measured by the methods of Kjeldhal [18]. Methods for the determination of ${ }^{3} \mathrm{H}-3$-glucose specific acitivity have been described previously [19].

\section{Calculations}

The glucose oxidation rate and energy expenditure values were calculated from calorimetric measurements for 5 -min intervals during the basal state and throughout the 3-h experimental protocol. Presented values for glucose oxidation, lipid oxidation, glucose infusion and energy expenditure represent the mean values for the $40-120 \mathrm{~min}$ time period unless otherwise indicated. After $100 \mathrm{~min}$ of somatostatin infusion alone, the plasma glucose concentration increased above basal levels in some subjects, even though the exogenous glucose infusion was discontinued [20-22]. To avoid the effects of hyperglycaemia per se on glucose metabolism, only the data up to 120 min were analyzed. In order to allow some period of stabilization after starting the somatostatin infusion, the $0-40 \mathrm{~min}$ time interval was not included in the calculation. To calculate steady state plasma glucose, insulin and NEFA concentrations during the study period, the mean of values (every $5 \mathrm{~min}$ for glucose and every $10 \mathrm{~min}$ for insulin and NEFA) from 40-120 min was employed.

Glucose production in the post-absorptive state was calculated by dividing the infusion rate of tritiated glucose (counts/min) by the steady state plateau of ${ }^{3} \mathrm{H}-3$-glucose specific activity (counts $/ \mathrm{mg}$ ). In the basal state, during conditions of constant euglycaemia, glucose uptake by all the tissues of the body must be equal to the rate of endogenous (hepatic) glucose production. Following the infusion of somatostatin, a non-steady state condition in glucose specific activity exists and rates of total glucose production and disposal were calculated using Steele's equations in the derivative form [23]. The value of 0.65 was used as the pool fraction. The rate of endogenous (hepatic) glucose production was calculated by subtracting the exogenous glucose infusion rate from the total rate of glucose appearance as calculated by the isotopic tracer technique.

All data are presented as mean \pm SEM. Statistical comparisons between and amongst groups were performed by unpaired and paired $t$ test analysis respectively. Coefficients of variations were determined by standard formulae.

\section{Results}

\section{Plasma Substrate and Hormone Concentrations}

The mean fasting plasma glucose concentration was similar in both studies $(5.3-5.4 \mathrm{mmol} / \mathrm{l})$ and was maintained close to the basal level during the somatostatin infusion period. The stability of the plasma glucose con- 
Table 1. Plasma glucose, insulin, glucagon, NEFA and catecholamines concentrations during the basal and the steady-state experimental period $(40-120 \mathrm{~min})$ for somatostatin alone and somatostatin with insulin replacement

\begin{tabular}{llllll}
$\begin{array}{l}\text { Plasma glucose } \\
(\mathrm{mmol} / \mathrm{l})\end{array}$ & $\begin{array}{l}\text { Plasma insulin } \\
(\mathrm{mU} / \mathrm{l})\end{array}$ & $\begin{array}{l}\text { Plasma glucagon } \\
(\mathrm{pg} / \mathrm{ml})\end{array}$ & $\begin{array}{l}\text { Plasma NEFA } \\
(\mu \mathrm{mol} / \mathrm{l})\end{array}$ & $\begin{array}{l}\text { Plasma adrenaline } \\
(\mathrm{ng} / \mathrm{ml})\end{array}$ & $\begin{array}{l}\text { Plasma } \\
\text { noradrenaline } \\
(\mathrm{ng} / \mathrm{ml})\end{array}$ \\
& & & & & $176 \pm 53$ \\
$5.3 \pm 0.05$ & $13 \pm 1$ & $96 \pm 8$ & $425 \pm 28$ & $37 \pm 8$ & $182 \pm 38$ \\
$5.3 \pm 0.05$ & $7 \pm 1$ & $30 \pm 6$ & $840 \pm 52$ & $44 \pm 9$ & $139 \pm 34$ \\
$5.4 \pm 0.05$ & $14 \pm 1$ & $68 \pm 7$ & & & $152 \pm 35$ \\
$5.4 \pm 0.05$ & $13 \pm 1$ & $36 \pm 5$ & $454 \pm 26$ & $48 \pm 6$ & $36 \pm 5$ \\
\hline
\end{tabular}

Results expressed as mean \pm SEM. Conversion factors: adrenaline $1 \mathrm{ng} / 1=5.46 \mathrm{pmol} / \mathrm{l}$; noradrenaline $1 \mathrm{ng} / 1=5.92 \mathrm{pmol} / 1$

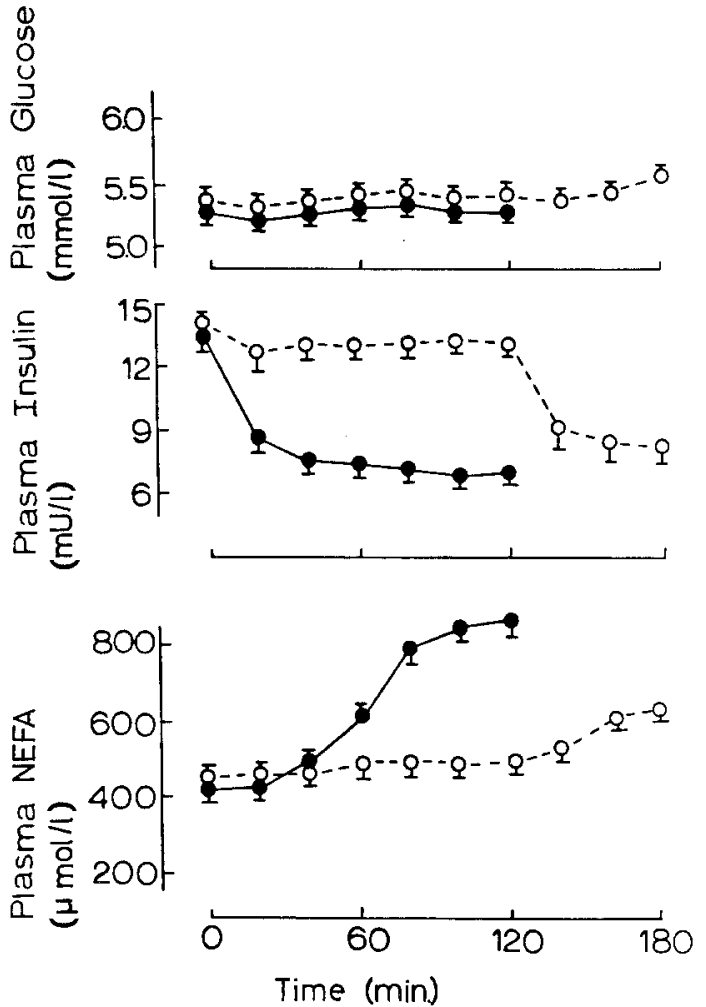

Fig. 1. Time course of plasma glucose, plasma insulin, plasma NEFA, and plasma glucagon concentrations during somatostatin alone (-) and somatostatin + insulin $\left(\mathrm{O}_{---O}\right)$. In the somatostatin + insulin infusion study, the insulin was stopped at $220 \mathrm{~min}$ while the somatostatin was continued. All values represent mean \pm SEM

centrations during the experimental protocol is reflected by the coefficient of variation which ranged from 1.8 to $2.9 \%$. During somatostatin infusion, the basal plasma insulin concentration $(13 \pm 1 \mathrm{mU} / \mathrm{l})$ declined rapidly and averaged about $50 \%$ of the fasting value $(7 \pm 1 \mathrm{mU} / 1)$. When insulin was infused with somatostatin, the plasma insulin concentration $(13 \pm 1 \mathrm{mU} / \mathrm{l})$ was not significantly different from the basal level. During both studies, the plasma glucagon concentration decreased by approximately $50 \%$ (Table 1 ). Plasma catecholamines did not change significantly during either protocol (Table 1). The mean fasting NEFA

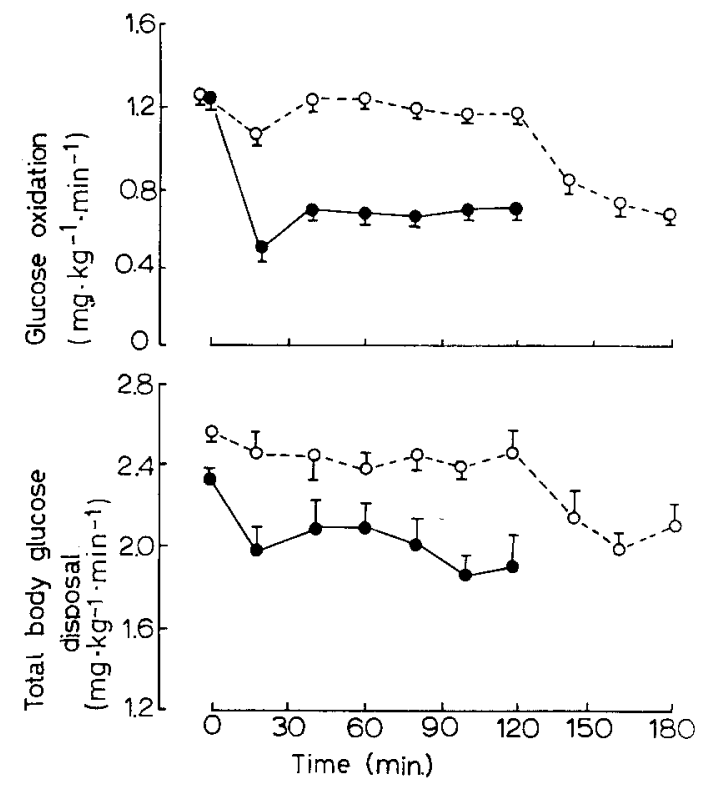

Fig. 2. Time course of the rate of glucose oxidation and total body glucose disposal during somatostatin alone $(-0)$ and somatostatin +insulin $\left(\mathrm{O}_{-}-\mathrm{O}\right)$. In the somatostatin +insulin infusion study, the insulin was stopped at 120 min while the somatostatin was continued. All values represent mean \pm SEM

concentrations were similar in both groups (425-454 $\mu \mathrm{mol} / 1)$. During the first $20 \mathrm{~min}$ following somatostatin, plasma insulin concentration had declined to $7 \pm$ $1 \mathrm{mU} / 1$ without any significant change in plasma NEFA levels $(440 \pm 48 \mu \mathrm{mol} / 1$; Fig. 1$)$. The plasma NEFA concentration remained stable during the first 40 min following somatostatin infusion. Thereafter, a progressive rise in NEFA levels was observed, reaching a value of $840 \pm 52 \mu \mathrm{mol} / 1$. With basal infusion replacement and somatostatin, there was no significant change in NEFA level from baseline $(496 \pm 38 \mu \mathrm{mol} / 1)$. Changes in plasma ketone levels paralleled those of NEFA. During somatostatin infusion, basal levels of $\beta$-hydroxybutyrate $(0.05 \pm 0.01 \mu \mathrm{mol} / \mathrm{l})$ and acetoacetic acid $(0.10 \pm 0.02 \mu \mathrm{mol} / 1)$ increased twofold. With somatostatin plus insulin replacement, ketone levels remained unchanged. 
Table 2. Glucose oxidation, lipid oxidation, and energy expenditure during the basal period and the steady-state experimental period $(40-100 \mathrm{~min})$ for somatostatin alone and somatostatin with insulin replacement

\begin{tabular}{llll}
\hline & $\begin{array}{l}\text { Glucose } \\
\text { oxidation } \\
\left(\mathrm{mg}_{\mathrm{kg}} \mathrm{kg}^{-1} \cdot\right. \\
\left.\mathrm{min}^{-1}\right)\end{array}$ & $\begin{array}{l}\text { Lipid } \\
\text { oxidation } \\
\left(\mathrm{mg} \cdot \mathrm{kg}^{-1}\right. \\
\left.\mathrm{min}^{-1}\right)\end{array}$ & $\begin{array}{l}\text { Energy } \\
\text { expenditure } \\
\left(\mathrm{mg} \cdot \mathrm{kg}^{-1}\right. \\
\mathrm{min}\end{array}$ \\
\hline $\begin{array}{l}\text { Somatostatin alone } \\
\quad \text { Basal }(n=9)\end{array}$ & $1.3 \pm 0.1$ & $1.0 \pm 0.1$ & $1.3 \pm 0.1$ \\
$\quad$ Steady-state $(n=9)$ & $0.7 \pm 0.1$ & $1.3 \pm 0.1$ & $1.3 \pm 0.1$ \\
Somatostatin + insulin & & & \\
$\quad$ Basal $(n=4)$ & $1.3 \pm 0.1$ & $1.0 \pm 0.1$ & $1.3 \pm 0.1$ \\
Steady-state $(n=4)$ & $1.2 \pm 0.1$ & $1.0 \pm 0.1$ & $1.3 \pm 0.1$ \\
\hline
\end{tabular}

Results expressed as mean \pm SEM

\section{Glucose Metabolism}

In the basal state, glucose oxidation was the same in both studies and was $1.3 \pm 0.1 \mathrm{mg} \cdot \mathrm{kg}^{-1} \cdot \mathrm{min}^{-1}$. Within 20 min after starting somatostatin infusion, glucose oxidation fell precipitously to $0.5 \pm 0.1 \mathrm{mg} \cdot \mathrm{kg}^{-1} \cdot \mathrm{min}^{-1}$ and remained low, averaging $0.7 \pm 0.1 \mathrm{mg} \cdot \mathrm{kg}^{-1} \cdot \mathrm{min}^{-1}$ during the $40-120$ min time period (Fig. 2). When insulin was infused with somatostatin, glucose oxidation during the $40-120 \mathrm{~min}$ time period averaged $1.2 \pm$ $0.1 \mathrm{mg} \cdot \mathrm{kg}^{-1} \cdot \mathrm{min}^{-1}$, a value similar to that observed during the basal state (Fig. 2). When insulin was discontinued at $120 \mathrm{~min}$, but somatostatin infusion was maintained, glucose oxidation declined by $0.4 \pm 0.1 \mathrm{mg}$. $\mathrm{kg}^{-1} \cdot \mathrm{min}^{-1}$ during the $120-180 \mathrm{~min}$ time period.

Basal hepatic glucose production $(2.3 \pm 0.1 \mathrm{mg}$. $\mathrm{kg}^{-1} \cdot \mathrm{min}^{-1}$ ) declined to $1.6 \pm 0.1 \mathrm{mg} \cdot \mathrm{kg}^{-1} \cdot \mathrm{min}^{-1}$ (20-120 min time period) following somatostatin alone. Glucose uptake by the entire body declined by $0.4 \pm$ $0.1 \mathrm{mg} \cdot \mathrm{kg}^{-1} \cdot \mathrm{min}^{-1}$ during the same time period (Fig.2). When insulin was infused with somatostatin, hepatic glucose production declined from $2.6 \pm 0.1$ to $2.0 \pm 0.1 \mathrm{mg} \cdot \mathrm{kg}^{-1} \cdot \mathrm{min}^{-1}$; total body glucose disposal did not change significantly (Fig. 2). When insulin was discontinued at $120 \mathrm{~min}$, but somatostatin infusion was maintained, total glucose uptake declined significantly by $0.4 \pm 0.1 \mathrm{mg} \cdot \mathrm{kg}^{-1} \cdot \mathrm{min}^{-1}$ during the $120-180 \mathrm{~min}$ time period.

\section{Lipid Oxidation (Table 2)}

In both studies, the basal lipid oxidation was $1.0 \pm$ $0.1 \mathrm{mg} \cdot \mathrm{kg}^{-1} \cdot \mathrm{min}^{-1}$. Following somatostatin alone, lipid oxidation increased to $1.3 \pm 0.1 \mathrm{mg} \cdot \mathrm{kg}^{-1} \cdot \mathrm{min}^{-1}$ $(p<0.01)$. When somatostatin was infused with insulin, no significant change in lipid oxidation was observed.

\section{Discussion}

In previous studies, we have examined the effect of hyperinsulinaemia on total glucose metabolism, glucose oxidation, and glucose storage in man [24]. Much less information is available concerning the effect of hypoinsulinaemia on the metabolic fates of glucose. It is commonly stated that the majority of glucose taken up in the basal state is insulin independent. However, it is difficult to find published data that directly address the effect of insulinaemia on glucose oxidation, glucose storage, and/or total glucose uptake in post-absorptive man. At least, five different studies have examined brain glucose oxidation under basal conditions and have reported values ranging from 0.8 to $1.2 \mathrm{mg} \cdot \mathrm{kg}^{-1}$. $\mathrm{min}^{-1}$ [25-29]. Many studies have established that, in post-absorptive man, glucose is the major oxidative fuel for cerebral tissues and until recently, it was believed that brain glucose uptake is independent of insulin [25-27].

Much less is known about the effect of insulin on the non-oxidative fate of glucose disposal in the basal state. If we assume that total body glucose utilization in the basal state is approximately $2.2 \mathrm{mg} \cdot \mathrm{kg}^{-1} \cdot \mathrm{min}^{-1}$ [1] and basal glucose oxidation is $1.2-1.3 \mathrm{mg} \cdot \mathrm{kg}^{-1} \cdot \mathrm{min}^{-1}$, then $0.9-1.0 \mathrm{mg} \cdot \mathrm{kg}^{-1} \cdot \mathrm{min}^{-1}$ must be utilized via non-oxidative pathways of glucose metabolism. As summarized previously [1], such non-oxidative pathways include recycling of glucose via glycolysis, re-uptake of glucose by splanchnic tissues, and perhaps other metabolic fates such as glucose conversion to lipid. To what extent oxidative and non-oxidative glucose uptake in the basal state is influenced by insulin is presently unknown.

In the present study, we have employed indirect calorimetry in combination with somatostatin to examine the effects of acute insulinopenia on glucose oxidation, non-oxidative glucose disposal, and total glucose uptake in post-absorptive man. It should be emphasized that the present results may not be applicable to conditions of chronic insulin deficiency. To minimize the well known effects of changes in glycaemia on glucose disposal, glucose was infused exogenously to maintain the fasting plasma glucose concentration constant. Thus, a condition was created in which extrahepatic tissues were acutely exposed to a lack of insulin while at the same time maintaining euglycaemia. Studies were not carried out beyond $120 \mathrm{~min}$ because of the development of hyperglycaemia that resulted as suppressed levels of hepatic production returned to normal or supranormal values [30, 31].

Under conditions of euglycaemic hypoinsulinaemia, basal glucose oxidation dropped precipitously within the first $20 \mathrm{~min}\left(1.3 \pm 0.1 \mathrm{mg} \cdot \mathrm{kg}^{-1} \cdot \mathrm{min}^{-1}\right.$ to $\left.0.5 \pm 0.1 \mathrm{mg} \cdot \mathrm{kg}^{-1} \cdot \mathrm{min}^{-1}\right)$ and remained suppressed thereafter. During the last $80 \mathrm{~min}$ (40-120 min time period) of hypoinsulinaemia, glucose oxidation stabilised at $0.7 \mathrm{mg} \cdot \mathrm{kg}^{-1} \cdot \mathrm{min}^{-1}$ a value nearly $50 \%$ less than was observed during the post-absorptive state. It is possible that the present results underestimate the quantitative effect of insulinopenia on the decline in glucose oxidation. Since the carbon products of glucose oxidation 
must traverse a large bicarbonate pool, sufficient time may not have elapsed to allow equilibration between various compartments. Against this possibility is the observation that glucose oxidation was constant during the last $80 \mathrm{~min}$ of somatostatin infusion. If failure to achieve equilibrium were a problem, one would have expected a small, progressive decline in glucose oxidation during this period and such was not the case. Lastly, it should be remembered that the technique of indirect calorimetry measures whole body glucose oxidation. Therefore, the present study cannot define which tissues are responsible for the somatostatin-induced decrease in glucose oxidation.

Several studies, both in vitro and in vivo, have shown that somatostatin per se has no direct effect on glucose uptake by hepatic, adipose or muscle tissues [32]. However, somatostatin is known to affect a variety of other hormonal and metabolic processes that may secondarily affect glucose utilization. Thus, it would be possible that the observed decrease in basal glucose oxidation was unrelated to the decline in plasma insulin levels. This question was examined in two ways. First, four of the nine subjects were restudied using the same somatostatin infusion protocol. During the repeat study, however, an exogenous insulin infusion was simultaneously administered to maintain the peripheral plasma insulin concentration constant at basal levels. When basal insulin levels were maintained, no decrease in glucose oxidation was observed. That the effect of somatostatin is mediated by insulinopenia is further suggested by the large decrease in glucose oxidation that ensued when the insulin infusion was stopped but somatostatin was continued (120-180 min time period). The decline in glucose oxidation to $0.8 \pm 0.1 \mathrm{mg} \cdot \mathrm{kg}^{-1}$. $\min ^{-1}$ was nearly identical to that observed when somatostatin was infused without insulin in study one. Although somatostatin may have other metabolic effects, the ability of (a) insulin alone to normalize glucose oxidation and (b) insulin withdrawal to reproduce the defect, strongly argue that the effects of somatostatin on glucose oxidation are mediated via insulinopenia.

We should also emphasize that we were able to inhibit insulin secretion by an amount that decreased peripheral insulin levels by only $50 \%$. Had we been able to inhibit insulin secretion completely, it is possible that an even greater decrease in glucose oxidation would have been observed. Thus, the present results provide only a minimal estimate of the amount of glucose oxidation that is dependent upon basal insulin secretion.

Finally, it is of interest to examine the effect of insulinopenia on the non-oxidative fates of glucose disposal. In our subjects under post-absorptive conditions, total body glucose uptake was $2.3 \pm 0.1 \mathrm{mg} \cdot \mathrm{kg}^{-1} \cdot \mathrm{min}^{-1}$ and of this, $1.3 \mathrm{mg} \cdot \mathrm{kg}^{-1} \cdot \mathrm{min}^{-1}$ were oxidized. Thus, approximately $1 \mathrm{mg} \cdot \mathrm{kg}^{-1} \cdot \mathrm{min}^{-1}$ was utilized by nonoxidative pathways. When acute insulinopenia was created with somatostatin, total body glucose uptake declined to $1.9 \mathrm{mg} \cdot \mathrm{kg}^{-1} \cdot \mathrm{min}^{-1}$.
Since glucose oxidation declined by $0.6 \mathrm{mg} \cdot \mathrm{kg}^{-1}$. $\mathrm{min}^{-1}$, it is clear that the entire decline in total body glucose metabolism can be accounted for by the fall in glucose oxidation. Thus, under basal conditions, the nonoxidative pathways of glucose metabolism appear not to be altered by an acute decline in the basal insulin concentration. The results of the combined somatostatin-insulin infusion provided additional support for the lack of effect of insulin on non-oxidative glucose metabolism under basal conditions. When somatostatin was infused, but basal insulin levels were maintained close to normal $(14 \pm 1$ versus $13 \pm 1 \mathrm{mU} / \mathrm{l})$, neither basal total glucose uptake nor glucose oxidation changed significantly. After $120 \mathrm{~min}$, the replacement insulin infusion was stopped but somatostatin was continued for an additional $60 \mathrm{~min}$. During this hour $(120-180 \mathrm{~min}$ time period), total body glucose uptake declined by $0.4 \mathrm{mg} \cdot \mathrm{kg}^{-1} \cdot \mathrm{min}^{-1}$ and this was paralleled by a decline in glucose oxidation of $0.4 \mathrm{mg} \cdot \mathrm{kg}^{-1} \cdot \mathrm{min}^{-1}$. These results provide additional confirmatory evidence that non-oxidative glucose utilization in the basal state is independent of insulin.

Acknowledgements. This work was supported in part by the Swiss National Science Foundation, grant No 3770080 , by the Raymond Berger Foundation for Diabetic Research in Lausanne, and by NIH grant AM 24092. We thank Mrs. D. Penseyres and Miss B. Mayland for their technical assistance and Miss M.C.Evraere and Miss M. Donner for their secretarial assistance.

\section{References}

1. DeFronzo RA, Jacot E, Maeder E, Felber JP, Wahren J (1980) The effect of insulin on the disposal of intravenous glucose results from indirect calorimetry and hepatic and femoral venous catheterization. Diabetes 30: 1000-1007

2. Rizza RA, Mandarino LJ, Gerich JE (1981) Dose response characteristics for effects of insulin on production and utilization of glucose in man. Am $\mathbf{J}$ Physiol 240: E630-E639

3. Kolterman OG, Insel J, Saekow M, Olefsky JM (1980) Mechanisms of insulin resistance in human obesity - Evidence for receptor and postreceptor defects. J Clin Invest 65: 1272-1284

4. Ferrannini E, Wahren J, Felig P, DeFronzo RA (1980) The role of fractional glucose extraction in the regulation of splanchnic glucose metabolism in normal and diabetic man. Metabolism 29: 28-35

5. DeFronzo RA (1979) Glucose intolerance and aging. Evidence for tissue insensitivity to insulin. Diabetes 28: 1095-1101

6. Jéquier $\mathrm{E}$ (1981) Long-term measurement of energy expenditure in: direct or indirect calorimetry? In: Björntorp P, Cairella $\mathbf{M}$, Howard AN (eds) Recent advances in obesity research III, John Libbey, London, pp 130-135

7. DeFronzo RA, Tobin JD, Andres R (1979) Glucose clamp technique: a method for quantifying insulin secretion and resistance. Am J Physiol 237: E214-E223

8. Statist Bull Metrop Life Insur Co (1959) 40, Nov-Dec

9. Dubois EF (1936) Basal metabolism in health and disease, 3rd edn. Lea \& Febiger, Philadelphia, pp 20-36

10. Lusk G (1924) Animal calorimetry: analysis of the oxidation of mixtures of carbohydrate and fat. J Biol Chem 59:41-42

11. Bursztein S, Saphar P, Glaser P, Taitelmann U, de Myttenaere S, Nedey R (1977) Determination of energy metabolism from respiratory functions alone. J Appl Physiol 42: 117-119

12. Herbert V, Lau KS, Gottlieb CW, Bleicher SJ (1965) Coated char- 
coal immunoassay of insulin. J Clin Endocrinol Metab 25: $1375-1384$

13. Aguilar-Parada E, Eisentraut AM, Unger RH (1969) Pancreatic glucagon secretion in normal and diabetic subjects. Am J Med Sci 257: $415-419$

14. Dole VP, Meinertz M (1960) Microdetermination of long-chain fatty acids in plasma and tissues. J Biol Chem 235: 2595-2599

15. Heindel JJ, Cushman SW, Jeanrenaud B (1974) Cell-associated fatty acid levels and energy-requiring processes in mouse adipocytes. Am J Physiol 226: 16-24

16. Williamson DH, Mellamby $\mathbf{J}$ (1974) D-(-)-3-hydroxybutyrate; acetoacetate; Methods of enzymatic analysis. Bergmeyer HU (Ed). Verlag Chemi, Weinheim RFA and Academic Press, New York, London, pp 1836-1843

17. Cryer PE (1976) Isotopic derivative measurement of plasma norepinephrine and epinephrine in man. Diabetes 25: 1071-1082

18. Hawk PB (1947) Kjeldahl method. In: Practical physiological chemistry, 12th edn. Blakiston, Toronto, pp 814-822

19. DeFronzo RA, Soman V, Sherwin RS, Hendler R, Felig P (1978) Insulin binding to monocytes and insulin action in human obesity, starvation and refeeding. J Clin Invest 62: 204-213

20. Lins PE, Efendic S (1976) Hyperglycemia induced by somatostatin in normal subjects. Horm Metab Res 8: 497-498

21. Sherwin RS, Tamborlane W, Hendler R, Sacca L, DeFronzo RA, Felig P (1977) Influence of glucagon replacement on the hyperglycemic and hyperketonemic response to prolonged somatostatin infusion in normal man. J Clin Endocrinol Metab 45: 1104-1107

22. Sherwin RS, Hendler R, DeFronzo RA, Wahren J, Felig P (1977) Glucose homeostasis during prolonged suppression of glucagon and insulin secretion by somatostatin. Proc Natl Acad Sci 74: $348-352$

23. Steele R (1959) Influence of glucose loading and of injected insulin on hepatic glucose output. Ann NY Acad Sci USA 82: 420-430

24. Thiébaud D, Jacot E, DeFronzo RA, Maeder E, Jéquier E, Felber JP (1982) The effect of graded doses of insulin on total glucose uptake, glucose oxidation, and glucose storage in man. Diabetes 31 : 957-963

25. Reinmuth OM, Scheinberg P, Bourne B (1965) Total cerebral blood flow and metabolism. Arch Neurol 12: 49-66

26. Scheinberg $P(1965)$ Observations on cerebral carbohydrate metabolism in man. Ann Int Med 62:367-371
27. Owen OE, Morgan AP, Kemp HG, Sullivan JM, Herrera MG, Cahill GF (1967) Brain metabolism during fasting. J Clin Invest 46: $1589-1595$

28. Owen OE, Reichard GA Jr, Boden G, Shuman C (1974) Comparative measurements of glucose, beta-hydroxybutyrate, acetoacetate, and insulin in blood and cerebrospinal fluid during starvation. Metabolism 23: 7-14

29. Huang SC, Phelps ME, Hoffman EJ, Sideris K, Selin CJ, Kuhl DE (1980) Noninvasive determination of local cerebral metabolic rate of glucose in man. Am J Physiol 238: E69-E82

30. Altszuler N, Gottlieb B, Hampshire (1976) Interaction of somatostatin, glucagon and insulin on hepatic glucose output in the normal dog. Diabetes 25: 116-121

31. Cherrington AD, Chiasson JL, Liljenquist JE, Jennings AS, Keller U, Lacy WW (1976) The role of insulin and glucagon in the regulation of basal glucose production in the postabsorptive dog. $\mathrm{J}$ Clin Invest 58: 1407-1418

32. Cherrington AD, Caldwell MD, Dietz MR, Exton JH, Crofford OB (1977) The effect of somatostatin on glucose uptake and production by rat tissues in vitro. Diabetes 26: 740-747

33. Gerich JE, Lorenzi M, Bier DM, Tsalikian E, Schneider V, Karam JH, Forsham PH (1976) Effect of physiologic levels of glucagon and growth hormone on human carbohydrate and lipid metabolism. J Clin Invest 57: 875-884

Received: 1 September 1982

and in revised form: 6 June 1983

Professor J.-P. Felber

Division d'Endocrinologie et Biochimie Clinique

Département de Médecine

C.H.U.V.

CH-1011 Lausanne, Switzerland

and

Dr. R. A. DeFronzo

Division of Endocrinology

Department of Medicine

Yale University School of Medicine

333 Cedar Street, Room 2074 LMP

New Haven, CT 06510, USA 